\title{
A study on detection of roving tension and fine control of yarn breakage DOI: 10.35530/1T.072.03.1757
}

\section{ABSTRACT - REZUMAT}

\section{A study on detection of roving tension and fine control of yarn breakage}

The fine control of yarn breakage is essential for the production of better yarn quality by reducing the tension fluctuation of roving. The detection of roving tension provides important information regarding the yarn formation during spinning. In the present work, we developed a device for roving-tension detection and regulation, which greatly reduces the yarn breakage rate and improves the production efficiency of ring spinning. By analysing the factors affecting the roving tensions, we used a signal acquisition system in conjunction with the tension detection device to regulate the spindle rotate speed to realize the fine control of yarn breakage. Our results indicate that the proposed method can ensure a uniform spinning tension of the yarn in ring spinning, which significantly reduces the yarn breakage rate, and boost the yarn production. Our work paves the way toward the rational production of high-quality yarn.

Keywords: spinning frame, spinning tension, intelligent control, spindle rotate speed, breakage rate

\section{Studiu privind detectarea tensiunii semitortului și controlul fin al ruperii firelor}

Controlul fin al ruperii firelor este esențial pentru producerea unor fire de calitate superioară, prin reducerea fluctuației tensiunii semitortului. Detectarea tensiunii semitortului oferă informații importante cu privire la formarea firelor în timpul filării. În lucrarea de față, s-a dezvoltat un dispozitiv pentru detectarea și reglarea tensiunii semitortului, care reduce foarte mult rata de rupere a firelor și îmbunătățește eficiența filării cu inele. Analizând factorii care influențează tensiunea semitortului, s-a folosit un sistem de achiziție a semnalului împreună cu dispozitivul de detectare a tensiunii pentru a regla viteza de rotație a fusului, pentru a realiza controlul fin al ruperii firului. Rezultatele indică faptul că metoda propusă poate asigura o tensiune uniformă de filare a firului în filarea cu inele, ceea ce reduce semnificativ rata de rupere a firelor și crește producția de fire. Lucrarea deschide calea către producția rațională de fire de calitate superioară.

Cuvinte-cheie: mașină de filat, tensiune de filare, control inteligent, viteza de rotație a fusului, rata de rupere

\section{INTRODUCTION}

The knowledge of spinning tensions is critical for improving yarn quality in a ring spinning frame. A suitable spinning tension is compatible with the strength of roving, which can improve the winding quality and reduce the breakage rate. On the one hand, an excessively large roving tension increases the occurrence of yarn breakage; on the other hand, if the roving tension is too low, it reduces the winding density and the yarn strength. Moreover, in the latter case, the size of the balloon is increased, which may increase the number of collisions between the balloon and anti-balloon plate and thus resulting in more hairiness and high breakage rates [1, 2]. Therefore, the detection of spinning tension is critical for the rational control of the yarn breakage in ring spinning. In general, the tension test includes a contact measurement method and a non-contact measurement method. For the contact measurement method [3, 4], the interaction between yarn and measuring device brings in additional friction forces, which changes the yarn trajectory in ring spinning and thus bringing errors into the measurement. For the non-contact measurement method [5,7], a detector monitors the yarn movement through the traveller. Once the yarn breakage occurs, the sensor generates electrical signals to stop the operation of the ring-spinning machine. However, it fails to detect the yarn breakage for the multi-channel drafted spun yarn [8, 9], in which the sensor cannot pick up the signal upon the breakage of one roving since another roving still moves through the traveller. Therefore, it is necessary to develop an effective method for detection and fine control of the breakage of ring spun yarn, since the currently existing theories and test means can hardly resolve the real-time dynamics of spinning tensions in overall spinning process, including twisting, ballooning and winding.

Two methods are commonly employed to regulate the spinning tensions to reduce yarn breakage, which are the based on single-phase two-speed polechange servomechanism [10] and transducer-controlled servomechanism [11], respectively. In the former case, a low-speed operation is adopted in the initial spinning stage, which is switched to the highspeed operation later on. In the latter case, the motor speed is adjusted in accord with the pattern of end breakage distribution of spinning bobbin $[12,13]$. 
However, the switch of rotor speeds in these two methods relies on the predetermined balloon height without taking into account the variation in winding radius as well as the dynamic changes of balloon height.

In the present work, we use a self-developed device to measure the roving tensions in ring spinning, in which the sensors are installed on the guide plate. The coupled physical-mathematical equations, which describe the evolution of the tensions, are solved to obtain real-time dynamics of roving tensions. Furthermore, we constructed a uniform tension control system, which proves to be an effective way to realize the fine control of roving tension.

\section{THEORETICAL MODEL}

\section{Analysis of spinning tensions}

The centre of the thread guide is denoted as $O$. $X$-axis, $Y$-axis and $Z$-axis pass through point $O$, in which $X$-axis is parallel to the plane that holds the guide plate; $Y$-axis is perpendicular to the plane that holds the guide plate; Z-axis is perpendicular to $X-O-Y$ plane. Therefore, a three-dimensional coordinate system is built with the centre of the thread guide as the origin. Similarly, the $X^{\prime}-Y^{\prime}-Z$ threedimensional coordinate system is built for the ring rail where $O^{\prime}$ is set as the centre of ring rail. Both the upstream and top ballooning tensions acting on the thread guide generate the stress signals via the stress sensor. As shown in figure 1, $T_{f}$ is the upstream tension of roving; $T_{q}$ is the top ballooning tensions; $F$ is the force acting on the thread guide and its projections on $\mathrm{X}$-, $\mathrm{Y}$ - and $\mathrm{Z}$-axis are $F_{x}, F_{y}$ and $F_{z}$, respectively; $\mu$ is the dynamic friction coefficient between yarn and thread guide, and $\sigma$ is the wrapping angle of yarn around thread guide. The stresses $F_{y}$ and $F_{z}$ can be measured through the bidirectional stress sensor. In addition, the perpendicular displacement of the guide plate can be measured through a displacement sensor installed on the guide plate.
According to figure $1, a$, the stress on the thread guide can be decomposed as:

$$
\begin{gathered}
F_{x}=T_{q 1} \sin \beta \cos \alpha \\
F_{y}=T_{q 1} \sin \beta \sin \alpha+T_{f} \cos \gamma \\
F_{z}=T_{q 1} \cos \beta-T_{f} \sin \gamma
\end{gathered}
$$

where $\gamma$ is denoted as the guide angle between the attenuated roving and the $X$-axis; $\beta$ is denoted as the top ballooning angle between the tangent line to the top of yarn-ballooning and the Z-axis; $\alpha$ is the angle between the $Y^{\prime}$-axis and the line passing through an arbitrary point in $X^{\prime}-Y^{\prime}$ plane.

According to Euler's formula:

$$
T_{f}=T_{q 1} \mathrm{e}^{-\mu \delta}
$$

Substituting equation 4 into equation 3 , the upstream tension $T_{f}$ can be written as:

$$
T_{f}=\frac{F_{z}}{e^{-\mu \delta} \cos \beta-\sin \gamma}
$$

There are two independent sensors installed at the guide plate to detect the horizontal and perpendicular stresses, i.e., $F_{x}$ and $F_{y}$, respectively, as shown in figure $1, b$. For calibrating the sensors, the horizontal sensor was placed vertically without load, and the output current of the transmitter was adjusted to be $5 \mathrm{~mA}$; then, a $150 \mathrm{~g}$ weight was added and the output current was adjusted to $20 \mathrm{~mA}$. The calibration of the perpendicular sensor was the same as that of the horizontal sensor. After all the sensors were calibrated as described above, the guide plate was placed horizontally, and the horizontal and vertical forces were reset to zero.

To verify the accuracy and reliability of the self-developed detection device, one end of the yarn was attached to the jaw of the front roller and the other end is hanged with a $50 \mathrm{~g}$ weight. Under the static tension, $\gamma=0^{\circ}, \alpha=0^{\circ}, T_{f}=T_{q}=50 \mathrm{cN}$. The guide angle $\beta$ can be calculated using the following equation:

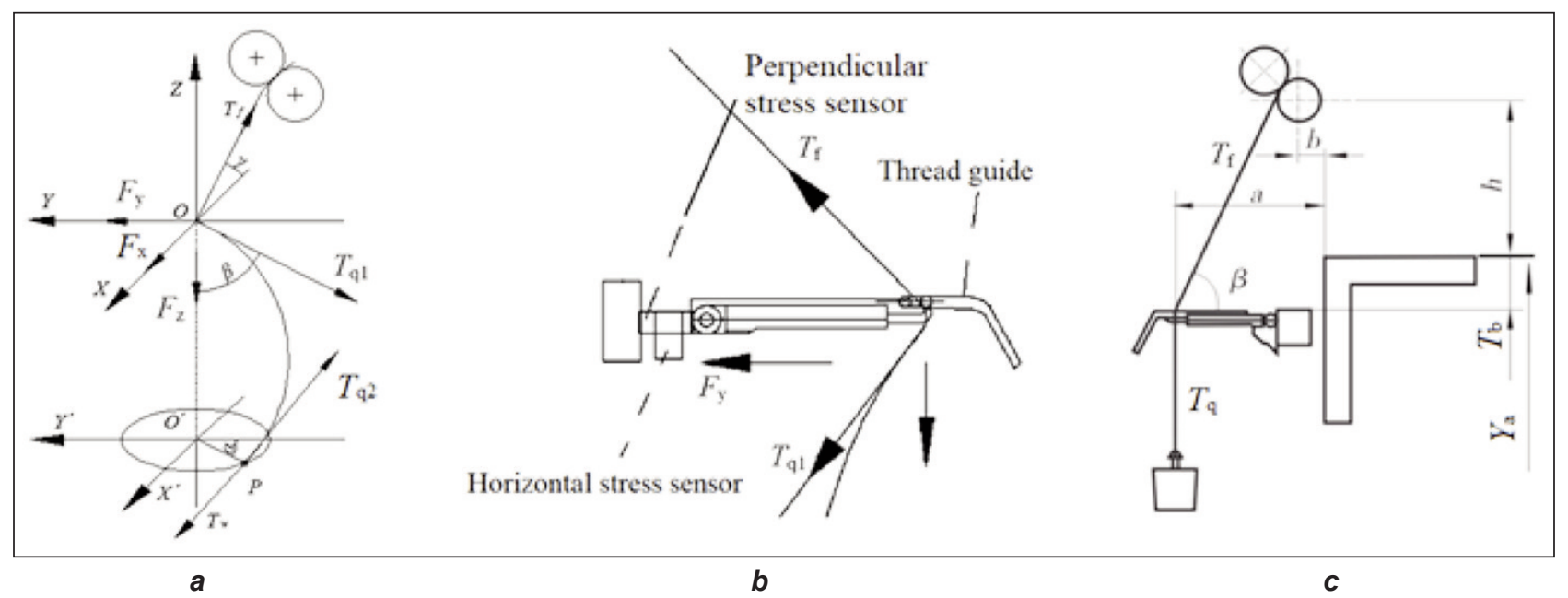

Fig. 1. Graphical presentation of: $a$ - analysis of the spinning tension; $b$-schematic diagram illustrating stress tensor; $c$ - schematic diagram illustrating static tension test 


$$
\beta=\tan ^{-1} \frac{h+Y_{a}+R_{G}-Y_{b}}{a-b-R_{G}}
$$

where a represents the distance from thread guide to the left side of ion plate $(88.8 \mathrm{~mm}), b$ - the distance from front roller to the left side of ion plate $(15 \mathrm{~mm})$, $h$ - the distance from the bottom roller to the top of iron plate $(95 \mathrm{~mm}), R_{G}$ - the radius of thread guide $(1.3 \mathrm{~mm}), Y_{a}$ - the height of iron plate $(48.4 \mathrm{~mm})$, and $Y_{b}-$ the height of guide plate.

As shown in figure $1, c$, when a $50 \mathrm{cN}$ weight is added to the thread guide, the $F_{y}$ is calculated to be $4.67 \mathrm{cN}$, and the $F_{x}$ is calculated to be $21.09 \mathrm{cN}$, based on the equations 1 and 2 , while $F_{y}$ is measured to be $4.72 \mathrm{cN}$ and $F_{x}$ is measured to be $20.86 \mathrm{cN}$ with the calibrated horizontal and perpendicular sensors. The measured values match with the calculated values very well, indicating the reliability of the selfdeveloped tension detection device.

Since the top ballooning angle $\gamma$ remains uncertain, so the equations 1-3 cannot be solved. The relation between the top ballooning angle and the wrapping angle is illustrated in figure $2, a$.

According to the geometric relationship shown in figure $2, b$, the relation between $\gamma$ and $\theta$ can be expressed as followings:

$$
\begin{gathered}
\operatorname{tg} \theta=\frac{F_{y}}{F_{x}} \\
\mathrm{e}^{\frac{\mu \pi \gamma}{180}} \cos (\theta+\gamma)=\frac{\sin (\beta+\theta)}{\mathrm{e}^{\frac{\mu \pi(90-\beta)}{180}}}
\end{gathered}
$$

Thus, we can calculate $\theta$ by measuring $F_{x}$ and $F_{y}$ using the self-developed tension detection device. Then, we obtain the using equation 8.

\section{Designing the fine control system of roving tension}

In general, the relation between spinning tension $T$ and spindle speed $n$ can be expressed as:

$$
T_{1}=T_{2}\left(\frac{n_{1}}{n_{2}}\right)^{2}
$$

The higher the spindle speed, the greater the spinning tension is. The frequency converter is used here to adjust spindle rotation speed to control the spinning tensions. On the one hand, during spinning, the dynamic stress signals are amplified and then converted by an A/D converter before being input into the CPU. On the other hand, the perpendicular displacement of the yarn guide plate is converted

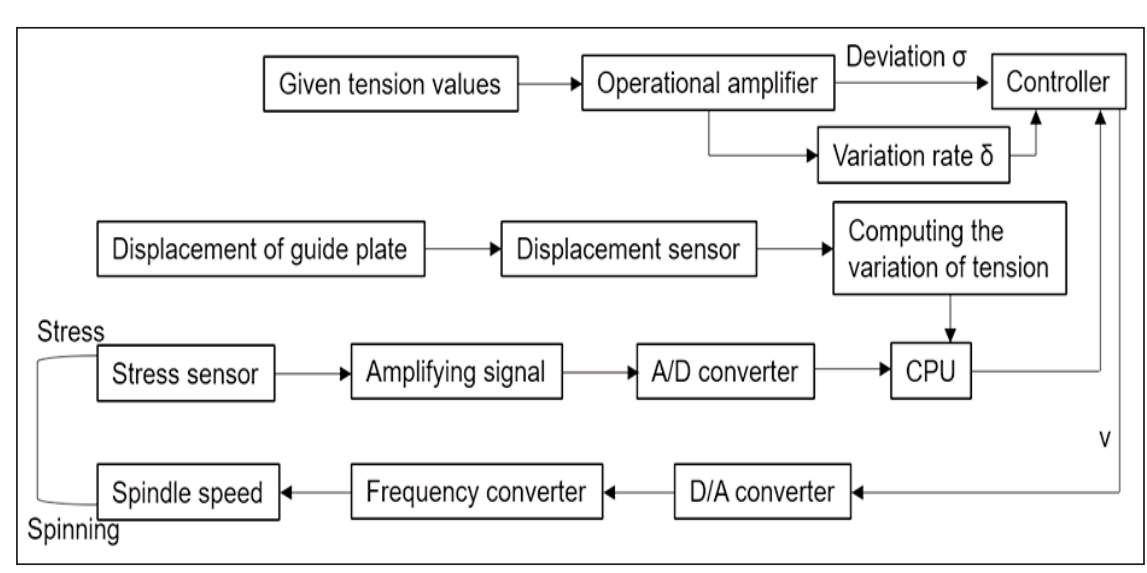

Fig. 3. Schematic diagram illustrating uniform tension control system 


\section{RESULTS AND DISCUSSION}

Figure 4, a demonstrates the tension variation within one cycle. It gradually rises as the ring rail moves upward from the lowest position and declines when it moves downward. The tension reaches the minimum value when the ring rail approaches the lowest position and the maximum value when the ring rail is close to the highest position.

We collected 12,241 test data during one cycle of up and down movement of ring rail. To facilitate the analysis, the average, maximum and minimum tensions were recorded, as shown in figure $4, b$. Table 1 summarizes the information about tension distribution and variation during the spinning process. According to figure $4, b$ and table 1 , the average tension at the beginning of spinning is $9 \mathrm{cN}$, so this stage is called the small-yarn stage. The average tension starts to decline below $9 \mathrm{cN}$ after 48 minutes, which is called the moderate-yarn stage. The average tension again increases above $9 \mathrm{cN}$ after 122 minutes, which is called the large-yarn stage.

To study the effect of the fine control system of spinning tension on spun yarn, the uniform tension control system was turned off, in which the maximum value of tension was observed to be $12.1187 \mathrm{cN}$. When the tension reaches $10.0 \mathrm{cN}$, and the uniform tension system was turned on. The average spindle speed was $11,917 \mathrm{r} / \mathrm{min}$ and 12,505 r/min before and after initiating tension control, respectively. Figure 4, $c$ shows the variations of tensions before and after initiating the uniform tension control system. After initiating tension control, the spindle speed was raised by $4.14 \%$; the standard deviation was fell by 0.72 percent; the coefficient of variation (CV) of tension was declined by $52.49 \%$. Table 2 lists the detailed experimental results. Table 3 lists the differences in yarn qualities before and after tension control. As revealed in table 3 , no significant difference is found in yarning quality before and after the tension control, but the total number of broken ends is significantly reduced.

As illustrated by the experimental data above, spindle speed can be utilized to control the spinning tension effectively. The converted electric signal output from the tension detector was compared with the designated tension value to control the frequency converter. When the tension is higher than the given value,

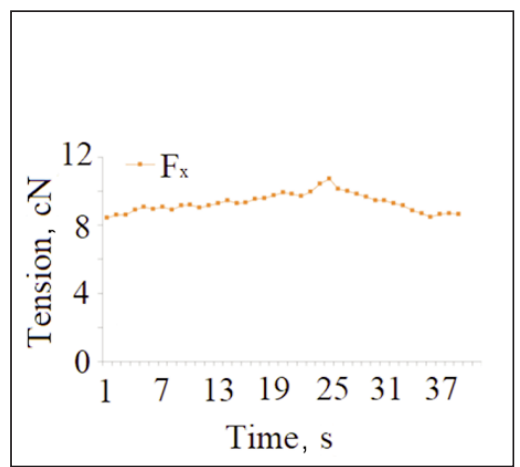

a

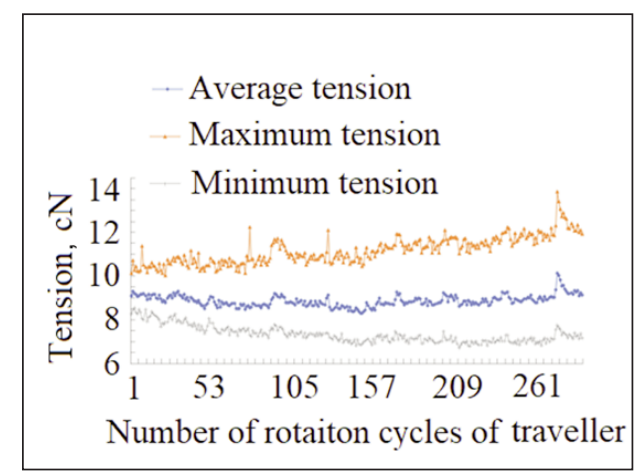

b

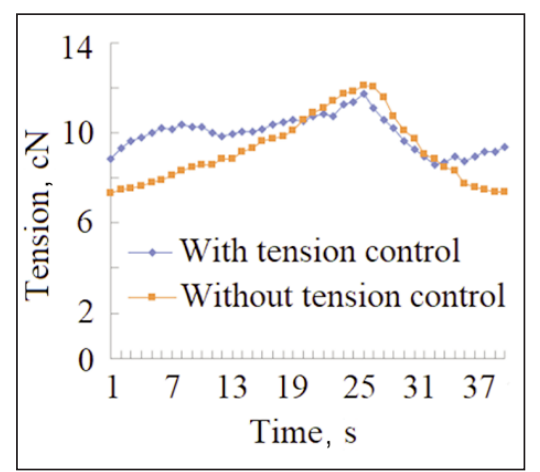

c

Fig. 4. Graphical presentation of: $a$ - variations of tension $\left(F_{x}\right)$ during an up-down cycle of the ring rail; $b$ - average, maximum and minimum $F_{X}$ during an up-down cycle of the ring rail; $c$ - comparison of tension $F_{x}$ before and after tension control

Table 1

\begin{tabular}{|c|c|c|c|c|c|c|}
\hline \multicolumn{6}{|c|}{ TENSION DISTRIBUTION AND VARIATION DURING ONE CYCLE OF UP AND DOWN RING RAIL MOVEMENT } \\
\hline Spinning process & $\begin{array}{c}\text { Average ten- } \\
\text { sion } \boldsymbol{F}_{\boldsymbol{x}} \mathbf{( c N )}\end{array}$ & $\begin{array}{c}\text { Standard } \\
\text { deviation }\end{array}$ & Tension CV & $\begin{array}{c}\text { Maximum } \\
\text { tension } \mathbf{( c N )}\end{array}$ & $\begin{array}{c}\text { Minimum } \\
\text { tension } \mathbf{( c N )}\end{array}$ & Range \\
\hline Small-yarn stage & 9 & 0.712 & 7.9 & 11.36 & 7.38 & 3.98 \\
\hline Moderate-yarn stage & 8.75 & 1.159 & 13.5 & 12.56 & 6.70 & 5.86 \\
\hline Large-yarn stage & 9.12 & 1.453 & 15.93 & 13.87 & 6.82 & 7.05 \\
\hline Overall process & 8.97 & 1.32 & 14.66 & 13.87 & 6.7 & 7.17 \\
\hline
\end{tabular}

DIFFERENCES IN SPINNING TENSIONS BEFORE AND AFTER INITIATING TENSION CONTROL

\begin{tabular}{|c|c|c|c|c|c|c|c|}
\hline $\begin{array}{c}\text { Frequency } \\
\mathbf{( H z )}\end{array}$ & $\begin{array}{c}\text { Spindle rotation } \\
\text { speed (r/min) }\end{array}$ & $\begin{array}{c}\text { Average } \\
\text { tension } \boldsymbol{F}_{\boldsymbol{x}}(\mathbf{c N})\end{array}$ & $\begin{array}{c}\text { Maximum } \\
\text { tension } \mathbf{( c N )}\end{array}$ & $\begin{array}{c}\text { Minimum } \\
\text { tension } \mathbf{( c N )}\end{array}$ & $\begin{array}{c}\text { Range } \\
\text { (cN) }\end{array}$ & $\begin{array}{c}\text { Standard } \\
\mathbf{d e v i a t i o n}\end{array}$ & $\begin{array}{c}\text { Tension } \\
\mathbf{( c N )}\end{array}$ \\
\hline 48 & 11917 & 9.23 & 12.12 & 7.33 & 4.79 & 1.49 & 16.08 \\
\hline 50.37 & 12505 & 10.02 & 11.74 & 8.56 & 3.18 & 0.77 & 7.64 \\
\hline
\end{tabular}




\begin{tabular}{|c|c|c|c|c|c|c|c|c|}
\hline \multicolumn{7}{|c|}{ YARNING QUALITY AND BREAKAGE BEFORE AND AFTER TENSION CONTROL } \\
\hline Quality & $\begin{array}{c}\text { Evenness } \\
\text { CV (\%) }\end{array}$ & $\begin{array}{c}\text { Thin sections } \\
\text { (number/km) }\end{array}$ & $\begin{array}{c}\text { Thick } \\
\text { sections } \\
\text { (number/km) }\end{array}$ & $\begin{array}{c}\text { Nep } \\
\text { (number/km) }\end{array}$ & \multicolumn{2}{|c|}{$\begin{array}{c}\text { Broken ends } \\
\text { distribution/single yarn }\end{array}$} & $\begin{array}{c}\text { Total } \\
\text { number } \\
\text { of broken } \\
\text { ends }\end{array}$ \\
\hline $\begin{array}{c}\text { With } \\
\text { tension } \\
\text { control }\end{array}$ & 17.34 & 42 & 140 & 286 & 4 & 10 & 2 & 25 \\
\hline $\begin{array}{c}\text { Without } \\
\text { tension } \\
\text { control }\end{array}$ & 17.27 & 30 & 114 & 284 & 13 & 23 & 5 & 60 \\
\hline
\end{tabular}

\begin{tabular}{|c|c|c|c|c|c|c|c|}
\hline \multicolumn{7}{|c|}{ Table 4} \\
\hline $\begin{array}{c}\text { Designated } \\
\text { frequency } \\
(\mathbf{H z})\end{array}$ & $\begin{array}{c}\text { Actual } \\
\text { frequency } \\
(\mathbf{H z})\end{array}$ & $\begin{array}{c}\text { Average } \\
\text { tension } \\
\boldsymbol{F}_{\mathbf{x}}(\mathbf{c N})\end{array}$ & $\begin{array}{c}\text { Maximum } \\
\text { tension } \\
(\mathbf{c N})\end{array}$ & $\begin{array}{c}\text { Minimum ten- } \\
\text { sion } \\
(\mathbf{c N})\end{array}$ & $\begin{array}{c}\text { Range } \\
(\mathbf{c N})\end{array}$ & $\begin{array}{c}\text { Standard } \\
\text { deviation }\end{array}$ & $\begin{array}{c}\text { Tension } \\
(\mathbf{c N})\end{array}$ \\
\hline 6.7 & 51.19 & 6.89 & 7.32 & 6.48 & 0.84 & 0.21 & 2.96 \\
\hline 6.9 & 50.89 & 6.95 & 7.36 & 6.03 & 1.33 & 0.32 & 4.62 \\
\hline 7.1 & 51.49 & 7.32 & 7.89 & 6.82 & 1.07 & 0.30 & 4.03 \\
\hline 7.3 & 51.77 & 7.40 & 8.74 & 6.19 & 2.55 & 0.23 & 3.06 \\
\hline 7.5 & 52.08 & 7.51 & 8.01 & 6.92 & 1.09 & 0.41 & 5.27 \\
\hline 7.7 & 51.76 & 7.72 & 8.21 & 7.27 & 0.94 & 0.24 & 3.06 \\
\hline 7.9 & 52.16 & 7.89 & 8.26 & 7.26 & 1.00 & 0.29 & 4.22 \\
\hline 8.1 & 53.68 & 8.01 & 8.54 & 6.37 & 2.17 & 0.39 & 5.35 \\
\hline 8.3 & 53.68 & 8.12 & 8.44 & 7.65 & 0.79 & 0.27 & 3.28 \\
\hline 8.5 & 54.61 & 8.46 & 9.44 & 7.77 & 1.67 & 0.42 & 4.98 \\
\hline
\end{tabular}

the frequency is reduced to a lower speed until they are equal; when it is higher than the given value, the frequency is raised to reach the given value. The effect of different frequency settings on tension is shown in table 4.

According to the experimental results listed in table 4, the deviation of actual tension from the designated value during the spinning process is within the range of $+0.22 \mathrm{cN} \sim-0.18 \mathrm{cN}$. The tension variation remains insignificant, and its non-uniformity is controlled within $6 \%$, which suggests the tension control system constructed hereby can alleviate the spinning tension fluctuation, and thus achieving uniform spinning tension.

Figure 5 shows the variation of tension against spindle rotation speed. During the tension test, the speed of spindle was set to be $7412 \mathrm{r} / \mathrm{min}(30 \mathrm{~Hz}), 8154$ r/min (33 Hz), 8922 r/min (36 Hz), 9664 r/min (39 Hz), 11407 r/min (42 Hz), 11149 r/min (45 Hz), 11917

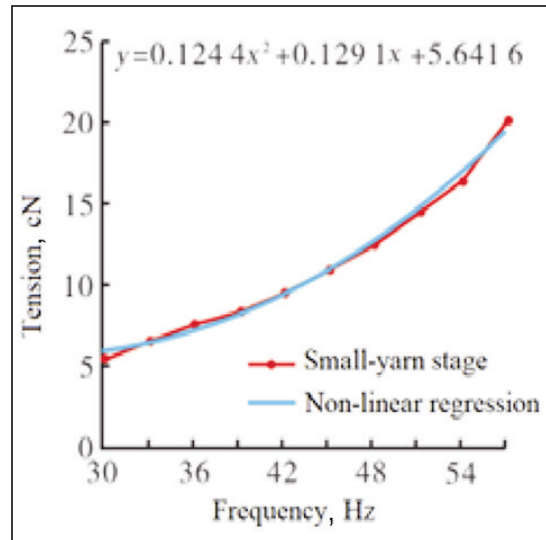

a

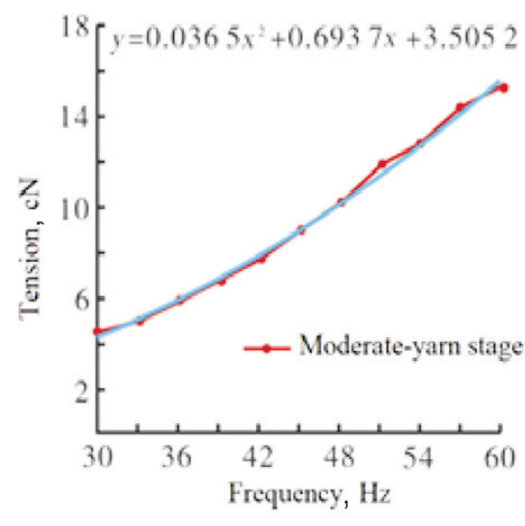

b

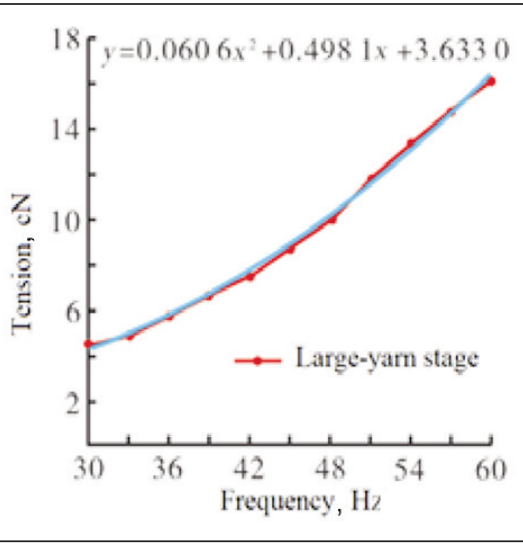

c

Fig. 5. Effect of spindle rotation speed on spinning tension $F_{x}$ in: $a$ - small-yarn stage; $b$ - moderate-yarn stage; $c$ - large-yarn stage 
r/min (48 Hz), $12647 \mathrm{r} / \min (51 \mathrm{~Hz}), 13389 \mathrm{r} / \mathrm{min}$ $(54 \mathrm{~Hz}), 14132 \mathrm{r} / \mathrm{min}(57 \mathrm{~Hz}), 14772 \mathrm{r} / \mathrm{min}(60 \mathrm{~Hz})$, and the ring rail was moved from the lowest place to the highest one. It can be seen from figure 5 that the relationship between the tension and spindle rotation speed is nonlinear, and the tension is increased with the increase of spindle rotation speed.

The effect of the type of traveller on spinning tension is summarized in table 2. Under the same spindle rotation speed, the mass of the traveller has a significant effect on the tension and CV. In particular, the larger the mass of traveller, the greater the tension is. The CV and range corresponding to the $8 / 0$ traveller are smaller than those of the other two travellers, suggesting that $8 / 0$ traveller has better operating performance.

\section{CONCLUSION}

In the present work, we constructed a novel tension detection and control system for the ring-spinning frame. The system, composed of stress sensor, $A / D$ and D/A converters, and data acquisition and processing systems, can be used to measure the dynamic stress on thread guide. The mechanical models are established and solved to obtain real-time dynamics of roving tensions. The spindle rotation speed can be regulated to control dynamics of roving tensions using the self-developed tension control system, which greatly reduces the fluctuation of spinning tension, alleviates the end breakage, and improves the yarning quality. Overall, the proposed spinning tension control method can be used for the intelligent control of spinning tension, which can effectively reduce the yarn breakage during ring spinning.

\section{REFERENCES}

[1] Tang, Z.X., Wang, L., Fraser, W.B., Wang, X., In-situ tensile properties of a ballooning staple yarn, In: Textile Research Journal, 2009, 79, 6, 548-554

[2] Tang, Z.X., Fraser, W.B., Wang, X., Modelling yarn balloon motion in ring spinning, In: Applied mathematical modelling, 2007, 31, 7, 1397-1410

[3] X, Q.Y., G, X.Q., Current Situation and Outlook of Yarn Tension Measurement and Control Technology, In: Cotton Textile Technology, 2011, 6, 25

[4] Nutting, T., Kinetic Yarn Friction And Knitting, In: Journal of the Textile Institute Transactions, 1960, 51, 5, T190-T202

[5] Chen, X.L., Mei, S.Q., Chen, X.B., Non-contact measurement of yarn tension in spinning process, In: Applied Mechanics and Materials, Trans. Tech. Publ., 2015, 367-372

[6] Xu, Q., Mei, S.Q., Zhang, Z.M., Measurement method of yarn tension based on CCD technology, In: Advanced Materials Research, Trans. Tech. Publ., 2011, 89-93

[7] Behera, B., Subramanian, S., Garg, A., Opto-electronic measurement of spinning tension, 2001

[8] Guo, M., Sun, F., Gao, W., Theoretical and experimental study of color-alternation fancy yarns produced by a double-channel compact spinning machine. In: Textile Research Journal, 2019, 89, 14, 2741-2753

[9] Guo, M., Sun, F., Wang, L., Xue, Y., Yang, R., Gao, W., Analysis of the appearance of two-color cotton yarn by the double-channel spinning system. In: Textile Research Journal, 2019, 89, 9, 1712-1724

[10] Eastham, J., McLean, G., Single-phase two-speed pole-change motors using phase-mixing techniques, In: Proceedings of the Institution of Electrical Engineers, IET: 1965, 1159-1172

[11] Silverman, D., Examining-sorting system with cyclic rejection means, Google Patents: 1969

[12] Prendžova, M., The effect of cotton yarn properties on yarn end breakage, In: International Journal of Polymeric Materials and Polymeric Biomaterials, 2000, 47, 4, 701-707

[13] Oana, I.P., Oana, D., Influencing factors analysis of tensile properties of wool yarns with different proportions of polyamide blend, In: Industria Textila, 2018, 68, 1, 277-280, http://doi.org/10.35530/IT.069.04.1437

\section{Authors: \\ CUI PENG, XUE YUAN}

Key Laboratory of Eco-Textiles, Jiangnan University, Wuxi, 214021, Jiangsu, China

\section{Corresponding author:}

XUE YUAN

e-mail: fzxueyuan@qq.com 